\title{
TRANSVERSE MYELITIS AND RHOMBOENCEPHALITIS IN A PATIENT WITH LUPUS
}

Letícia Lopes Coimbra (HOSPITAL GERAL DE PALMAS. UNIVERSIDADE FEDERAL DO TOCANTINS., Palmas, TO, Brasil), Antônio Rêgo Clemente de Jesus (Hospital Geral de Palmas, Palmas, TO, Brasil), Danilo Garcia Ruiz (Hospital Geral de Palmas. , Palmas, TO, Brasil), Allethéa Robertha Souza e Silva (Hospital Geral de Palmas, Palmas, TO, Brasil), Maria Eduarda Guimarães Leal (Hospital Geral de Palmas. Universidade federal do Tocantins., Palmas, TO, Brasil), Daniela Maria Edilma Japiassú Custódio (Hospital Geral de Palmas, Palmas, TO, Brasil), Rafaela Alen Costa Freire (Hospital Geral de Palmas, Palmas, TO, Brasil), Paulo Geovanny Pedreira (Hospital Geral de Palmas, Palmas, TO, Brasil), Hugo de Carlos Maciel Rossoni (Hospital Geral de Palmas, Palmas, TO, Brasil), Paola Bottin Madrid (Hospital Geral de Palmas, Palmas, TO, Brasil)

\section{BACKGROUND}

The manifestations of MTA (acute transverse myelitis) come from the dysfunction of motor, sensorial and autonomic pathways. Some studies report an incidence of $1 \%$ in the neuropsychiatric manifestations of SLE. With a bimodal peak between the ages of 10 to 19 years and 30 to 39 years. During the acute phase, the treatment aims to prevent and distort the process and stop any progression of the disease. The long way objectives intends to avoid the damage in the spinal cord or loss of function. Involvement with the major(s) organ(s) denotes a worse prognosis. Tetraplegia, paraplegia, paraparesis, sensorial loss or sphincter dysfunction are the main comorbidities. Rhombencephalitis, inflammation of the hindbrain (trunk and cerebellum) has infectious, autoimmune or paraneoplastic etiologies, being an infection by Listeria spp. the most common cause.

\section{CASE REPORT}

GGM, 15 years old, female, white, with diagnosis of Juvenile Systemic Lupus Erythematosus at 9 years of age (Nephritis, malar rash, photosensitivity, FAN positive, native anti-DNA reagent, complement consumption and oral ulcer) in remission of the disease with the use of Mofetila Mycofelonato, Hydroxychloroquine and Captopril. He entered the hospital with holocranial headache mainly in the frontal region of progressive onset about 3 weeks ago associated with photophobia, phonophobia and vertigo. He also reported treatment of sinusitis with Amoxicillin + Clavulanate for 14 days in the mentioned period. Headache was intensifying associated to the reduction of motor force and tactile sensitivity in the lower limbs of way up to the hip region, fever, neck stiffness and bladder overdistension. Magnetic resonance showed signs of MTA and hypersignal myelitis in the hindbrain, mainly to the left, suggestive of rhomboencephalitis or optic neuromyelitis. CSF was suggestive of viral infection with bacterial overlap, and Ganciclovir, Cefotaxime and Ampicillin + Sulbactam were started. He progressed with abducent nerve palsy and bilateral papilledema. There was improvement of the ophthalmological complaint and the infectious symptoms, but with paraplegia ascending up to nipples height. Pulse therapy with methylprednisolone $1 \mathrm{~g} /$ day for 3 consecutive days and 1 dose of cyclophosphamide. He wasdischarged after treatment of rhombencephalitis, still presenting diplopia, paraplegia up to waist height, need for relief catheter.

\section{CONCLUSION}

We describe the case of a young female patient with SLE who developed severe neurological involvement, required immunosuppression and antibiotic therapy and developed residual paraplegia, uncontrolled bladder and altered sensitivity. 